\title{
HISTORY OF COMMUNITY HOUSE SIOUX CITY, IOWA
}

(This article was prepared from data collected by a special committee of the Community House Board. It was written and edited by Miss Mabel F. Hoyt, head of the Adult Education Department of Community House.-Ed.)

History is written on a framework of dates and epochs, on source documents and maps. Settlement houses are built in neighborhoods by magnetic personalities who possess the power to give a vital philosophy to a community, and if this combination of personalities and ideals is successful, the settlement house, whether it be Hull House in Chicago or the Henry Street Settlement in New York, may widen its sphere of influence from the provineial neighborhood to the ends of the earth. As scenes shift and time moves on, a neighborly attitude in the minds of many individuals may change the complexion of history.

One of the settlement houses which is making an imprint on the social history of the middle west is Community House in Sioux City, Iowa. Its success can be attributed to a vital need for its existence, a devoted board of women who had faith in its future, and to an inspired staff who led out to new and wider fields of service.

The origins of Community House lay in the rude awakening of all the United States to the need of remedying the situations revealed by the World War, when men from every walk of life and from all localities were called to the service of their country.

The opening scene in the history of Community House in Sioux City took place in 1921 . The Y. W. C. A. in Sioux City recognized that one of the grave problems revealed by the war was the need for the assimilation of a large foreign population into the life of the community. On the advice of one of the national secretaries of this organization, a survey was made and it was found that the people of certain nationalities lived very much to themselves and had little or no 
contact with any other group.' For example, twenty-seven children of a certain nationality, born in this country, could neither speak nor understand English on entering the public schools. It was necessary to place them in a room by themselves until they were somewhat conversant with the language. This amazing situation emphasized the need of providing some opportunity for the foreign-born to meet and mingle with other groups if they and their children were to take part in eommunity life.

On the Y. W. C. A. board at that time, Mrs. William Milchrist was serving as chairman of the Americanization committee. The need fired in her a determination to do something to meet this problem.

It was decided to establish a community house, and the Y. W. C. A., realizing that the best results would be secured if it were not under the auspices of a religious organization, turned the work over to a group of women from various sections of the city representing Jewish, Catholic, and Protestant faiths. It was conceded also by all those interested that the community house must be situated in the heart of the industrial district so that the spirit of neighborliness might be lived.

The district in which the new community house was to function lies at the lower eastern end of the main business district of Sioux City; it separates that district from one of the more important suburbs of the city, that in which Morningside College, a Methodist institution, is located. To the home owners of Morningside, who must pass through the region on their way to and from work, the lower east side has always been an eye-sore.

This region is itself separated from the business district of the eity by two blocks of railroad tracks, which are spanned

1. There is no record as to how thorough or extensive the survey made by the Y. W. C. A. in 1921 was. Although no figures are available to show the number of persons in each of the nationality groups then living in the district later to be served by Community House, the following have been recorded in the activities of Community House: Armenian, Bohemian, Chinese, Danish, French, German, Greek, Italian, Jewish, Bulgarian, Lithuanian, Mexican, Norwegian, Persian, Polish, Rumanian, Russian, Spanish, Syrian, and the Negroes. 


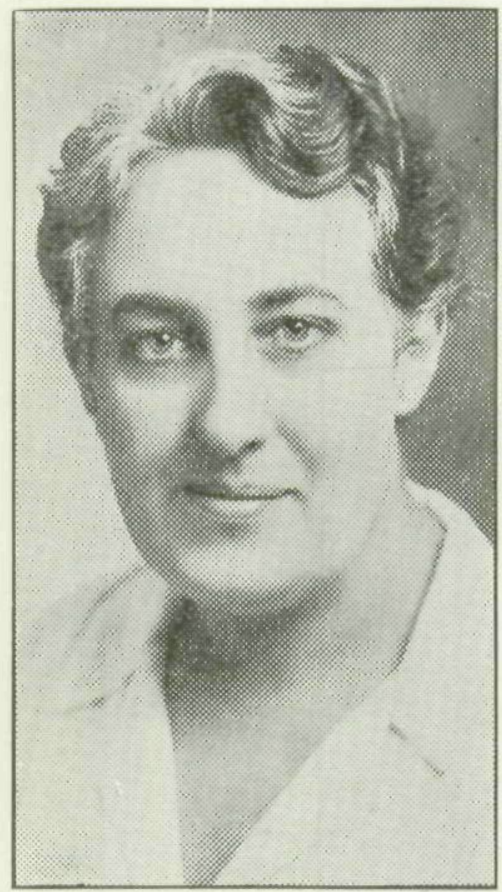

MARY J. TREGLIA

Exec. See. Community House, Sioux City

by a viaduct. The coal and lumber yards of the city are centered here, and the freight depots and warehouses as well. The Floyd River, which has played such a tragic role in the history of the neighborhood, flows through the center of the district. South of the Community House neighborhood, toward the mouth of the Floyd River, are located the large stock yards and packing houses which constitute the main industry of Sioux City.

Chiefly employed in the packing houses, Cudahy's, Swift's, or Armour's, nevertheless, all of the people in the neighborhood belong to the low income group, and are, for the most part, of foreign extraction. A large number of these steady and thrifty laborers were induced to build homes in the district because of the cheap property values, and because of attractive offers from building loan companies. Most of the 
cheap frame houses in the district, however, were built by real estate investors for a low wage group, and little attention was given to the upkeep of the property. As time went on, Oemig Row and similar areas, have deteriorated into practically unlivable quarters.

A rather unique feature of the population of this area is that the people are not of one nationality group, as is sometimes the case in a foreign neighborhood, but represent twentyone different nationalities. The area is served by three small churches: a struggling Italian Roman Catholic Mission, a starving Russian Orthodox Church, which, because of conflicting groups within the parish, calls a new priest to lead them on an average of once every six months, and a poor but spirited Negro Baptist Chureh.

After the decision had been made that Community House should be established in this district, all available locations were inspected by the committee. The quarters most adaptable to the purpose, and centrally located, were situated on the second floor of the two-story frame building which housed the Edwards and Browne Lumber Yards at 1604 E. 4th Street. Arrangements were made, and Community House began to take form.

In the beginning the rooms were cheerless, bare and covered with dust; but they oftered possibilities and suited the needs. There were no funds, no furniture, but an abundance of faith. Mr. Browne, the landlord, gave assurance there was no need to worry about the rent until there were funds in hand. The early workers were heartened, too, by the increasing interest and eo-operation promised by the eitizens of Sioux City. Many individuals and organizations responded to the S. O. S. for furniture, and in a surprisingly short time the cheerless rooms were made comfortable and home-like.

On April 7, 1921, the opening meeting at Community House was held-marked by its great success and enthusiasm.

The Y. W. C. A., although it turned over the sponsorship of the Americanization project to the non-sectarian group of women, agreed to pay the first year's salary of the executive secretary who was to live at Community House and launch the program. The first secretary was Miss Dorothy Anderson. 
She was a unique personality_good looking, intelligent, vivacious. She had a love of music and of beauty in all forms, and because of this recognition of universal values she made her influence felt in the neighborhood. Previous to the day on which Community House was scheduled to open, she made a thorough eanvass of the neighborhood, and secured many beautiful pieces of handeraft of all sorts as well as interesting curios from foreign lands. From these she assembled a surprisingly ereditable exhibit for the initial meeting. Those in charge had feared that the foreign-born people might be reluctant to come to the new Community House, but on the contrary, so many eame that it was necessary to receive them in installments. The quarters proved too limited even on the first night.

The neighborhood idea eaught hold and grew, and soon it was necessary to furnish Miss Anderson with an assistant. Miss Mary J. Treglia was appointed to this position in 1922. Her parents were Italian immigrants. She knew the problems of all these people in a strange land and was destined to play an important role in the years ahead.

On the walls of one of the rooms, shelves were built and served as the beginning of a library. A call went out to those who were willing to donate books to this new project of Community House. Members of the public library staff volunteered to catalogue the volumes received. Magazines were placed in the racks and the long corridor-like room between the north and south rooms took on the appearance of a library.

These were pioneer days and the growing process of Community House was not simple. Centuries of prejudice between creeds and nations could not be suddenly surmounted. It took much diplomacy to have Jews and Gentiles work together, to have Mohammedans and Christians sit at the same table, and women in elubs exchange recipes for Irish stew and Italian spaghetti.

Although creditors were sympathetic, the governing board of Community House realized that bills for rent, light and gas, and office supplies, ete., must be paid. On October 15th, 1921, a tag day was staged on the streets of Sioux City and 
the proceeds from this scheme provided adequate funds to carry the expenses through all the first year. By November, 1922, the eity had recognized the value of Community House as a civic enterprise and from then on, up to the present time, Community House has always been a member of and received its support from the Community Chest Fund.

Finances are always an essential factor in the maintenance program of an institution. Community House from its earliest history has worked on a small budget, but has been fortunate in having Mrs. Osear Ruff as treasurer of the Board for practically its entire existence. Her careful planning of the budget, her sense of values, her interest in the people, and her sincere desire to have Community House serve the community to its fullest eapacity perhaps accounts for the fact that the Community House has never been in debt, and yet has reached a remarkable peak of achievement.

Tribute should be paid to the first board of Community House which served so well to make its initial start a successful one. The board was composed of Mrs. William Milchrist, President; Mrs. H. P. White, Vice President; Mrs. E. J. O'Donnell, Secretary; Mrs. L. R. Manley, Treasurer; Mesdames R. H. Burton-Smith, F. L. Hutchins, T. B. Hutton, Walter Frane, J. L. Browne, Wahlstrom, Winifred Sloan, Emil Marx, Richard Zwemer, H. H. Krumann, Osear Ruff, James Q. Keeffe, and the Misses Grace Atchinson and Margaret Manley. These ladies devoted hours of service to the eause, helped teach the women American ways of dress, of cooking, and of thinking. These board women also helped to sell this neighborhood house idea to citizens of Sioux City who were at that time unaware of its existence.

Much of the success of this early period was due to Mrs. Milchrist who served as first president of the Community House Board. Her enthusiasm in the days when faith in the venture was essential, and her loyalty to Miss Anderson, the secretary, in her struggle to establish Community House, were responsible in a large measure for the settlement house weathering the early storms of uncertainty.

It is the purpose of a settlement house to offer activities to all ages and to all members of the family. The children were 
drawn to the center by means of clubs and recreational organizations. A different group of little youngsters came to the playroom every afternoon. Early in the history of the House, members of the Junior League told stories, provided games, and gave instruetion in handwork. These groups and clubs provided a means of keeping the children off the streets and created an environment which was wholesome and constructive. From the very beginning of its activities, Community House gave promise of justifying the faith of its founders.

In view of the fact that the Americanization program was one of the reascns for the establishment of Community House, classes were organized for those preparing to take citizenship examinations in which they might receive their preliminary training. Because so many of these people could not read nor write it was necessary to give work in primary subjects before the complex civic instruction could begin. To these elasses there eame for instruction a Russian priest, an Italian who worked in the slaughter room at the packing house, a Mexican worker on a railroad section gang, a German boy who had recently graduated from a German university, a woman who had been a photographer in a little village in Denmark, an Armenian who had seen his family annihilated in a Turkish massacre. These sat around the tables in the night school elasses and, in the exchange of experiences and philosophies, broke down barriers, and eaught new ideas. ${ }^{2}$

Because more and more people were attracted to the varied activities of Community House, it was impossible for the staff alone to take eare of the entire program, so volunteers were interested in the work and assumed leadership of classes and clubs. These volunteers, after they had served a few weeks, eame to the realization that they were receiving more inspiration and knowledge from this service experience, than they could ever return to these people whom they were supposed to be teaching. In 1930 the Board of Edueation of the Public Schools furnished a teacher for this night school.

2. The Americanization classes were held exelusively at night for the eonvenience of the working men at first. Later on, afternoon classes were developed for women or for those men who were not working; this oceurred during the depression, about 1933. 
1925 saw the beginning of changes and the entrance of Community House into a new era. In that year Miss Dorothy Anderson resigned to go into a new field of activity. Mrs. William N. Ford was chosen as the new head of the governing board of Community House. This Board elected Miss Treglia as the successor to Miss Anderson. Three years later, in 1928, Miss Arlone B. Kinkaid, who had been acting as a volunteer worker, was eleeted to act as Miss Treglia's assistant.

A settlement house, because it is situated in a district populated by people of low economic income, always has its finger on the pulse of social unrest. The unrest evidenced in the Community House district was largely attributable to economies factors, and conditions resultant therefrom.

Many of the residents in the neighborhood had bought property because it was cheap, had built small homes, and had paid heavy loan charges to eover the costs. Low wages in the packing house and a falling off of the employment was another cause of unrest; the tension of the threatening strikes that ran coneurrent with the latter, laid upon Community House workers the strain of attempting to keep an even keel in these trying times. Then, over this district, every spring and fall, there hung the menacing fear of floods.

There has always existed the danger of floods in the spring and fall in the Sioux City region of the Floyd River valley. In some years the water would rise, but stay within the river banks, and the next year the rise would be of such a degree that the whole area would be inundated so that it would be necessary for the police and rescue workers to patrol the district in out-board motor boats, from 4th Street, which is the main thoroughfare, to 27 th Street. This danger of high water was perhaps the reason for the low real estate costs, and was also responsible for a fatalistic belief in the minds of the people that complete destruction to their property was within the range of reason. It is significant that the one bright spot in this drab area is also identified with the flood. A small piece of land about 11/2 blocks square was landscaped and set aside as a park in 1921 and ealled Anderson Park, after Andrew Anderson, one of Sioux City's heroes who was responsible for saving 26 lives in the disastrous flood of 1892 . 
In 1926 Community House was ealled upon to take the lead in reconstructing the physical damage that was done by the disastrous flood of that year, and to re-build the morale of the people who had suffered the losses.

All of these undertones of unrest in the community's life were familiar to Community House, and more besides, due to the unique feature of its group work, which was all carried on by the ease work approach. Miss Treglia soon gained the confidence of the people of the district and built up a reputation for an ability to handle difficult eases, as a result, a steady stream of individual cases was presented for her advice and consideration. The problem of an adolescent girl, or the unadjusted marital relations between husband and wife, or the question of securing employment, or the discipline problem between a foreign born parent and an Americanized son or daughter, who felt that their parents were old fashioned and uninformed .... all these were part of the important work of the secretary.

Several interesting clubs which have had a prominent part in meeting these social-economic problems were organized in this phase in the history of Community House. The Alpha Sigma was made up of girls who had finished school and were working in offices, stores and factories, and who needed some social contacts. This club is still in existence and furnishes volunteer workers to all the activities in Community House.

The Women of All Nations Club has proved another interesting experiment, and illustrates, perhaps better than anything else, the growth of Community House. In the beginning, Miss Anderson and Miss Treglia walked the streets knocking at the doors of all the houses in the block, urging these women to come to classes and elubs. Most of them were unable to speak English and had no direct contact with the outside world. Although they reluctantly entered this new social experience, they soon learned that life was not all drudgery and that domestic problems did not have to assume such an overwhelming place. In becoming members of this Women of All Nations Club, they exchanged recipes, listened to good music, laughed with each other, and developed a spirit of courage and gained a more optimistic outlook on life. This 
club, which constitutes the backbone of the family group, still is considered one of the most important groups in the Community House program.

Yet the activities of Community House were not all recreational-for it attempted also to encourage a cultural growth. The people in the neighborhood eame from national and racial stocks each of which has a long and distinetive record of cultural history, and these people, as heirs of that background, possessed on the whole a deep and sincere appreciation of all the arts. Art displays from the art classes were presented in exhibits. An exquisite Chinese embroidery, a gift from two Chinese boys in the Adult Education classes, was hung on the wall of the big north room. Miss Kinkaid gave violin lessons to those who showed promise of musical ability. Clubs were organized for dramatic work, and it was a source of a great deal of pride to the distriet that Community House was awarded the first prize in the inter-city one-act play contest in 1931.

The program was growing by leaps and bounds. New groups were organized, and the list of volunteers who were in charge of boy and girl scout activities, homemakers, handcraft work, dramaties, sewing, adult education, athleties, now numbered one hundred. The second floor of the frame building which housed the lumber yards was taxed to eapacity. On nights of special programs, the rickety old stairs to the upper floor were so weighed down with youngsters and adults who could not get into the crowded rooms, that those in charge held their breath lest the tremendous weight of humanity cause the building to collapse. Physical aspects of the housing problem became so serious that in 1931 the authorities condemned the quarters as a fire hazard.

In the fall of 1930 the Board of Education announced that the Lineoln School was to be closed. It was like a bomb exploding in the neighborhood. This was a small school in which were teachers who understood the peculiar problems of the neighborhood and who had the patience to realize that education was not merely the routine of the elassroom. The plan was to transport the children to larger buildings some distance away from the neighborhood. In spite of protests, 
parades, and bitter antagonism, the building was torn down and one more difficulty was added to the many confronting the staff of Community House.

Unemployment reached new heights. Packing house employees were laid off. Agitators made inroads into discontented groups.

The razing of the only school in the neighborhood and the inability of the school board to provide funds for a new building left Community House the one remaining stabilizing influence in the immediate district. With the Community House building condemned, the choice lay between finding some place to move or discontinuing operations. Diligent search was made for quarters but it was without success. It was now either build or cease the Community House program. Realizing that a crisis existed, the Board of Directors faced the serious situation and appointed a building committee of six with Mrs. Arthur Sanford as chairman.

It had been a dream on the far horizon that some day Community House might have a building of its own, and $\$ 750$ had been set aside for that purpose. The building committee realized this $\$ 750$ was rather insignificant for the task which had been assigned to them, particularly in view of the fact that the rumblings of the Wall Street Crash had already been felt in the Middle-West to no small degree. However, in spite of 1932 marking one of the worst depressions in history, Miss Treglia and the building committe pushed forward undismayed into that most interesting chapter in the history of Community House, in which the ingenious scheme for financing the building was conceived and successfully executed.

The City Couneil was persuaded that the discontinuance of Community House would be a serious loss to the welfare of the city. Mr. Milton Perry Smith, who was head of the Department of Parks at that time, became vitally interested in the situation and in the ambitious project which the Community House Board had launched. He promised that they might count on county relief labor, which was being financed through RFC funds, to do the construction work, 
if the building materials were furnished by the Community House Board.

The School Board was induced to transfer the abandoned Lincoln School site, across the street from Anderson Park, to the eity which in turn gave Community House the use of the property. Ground was broken in February, 1933, but on the day following this eeremony, the bank in which the $\$ 750$ was on deposit, elosed its doors! Even this blow did not daunt the enthusiasm of this determined group.

A Buy-A-Brick Campaign was organized. The eity was canvassed, and in spite of depressed spirits and flat purses, the committee met with a remarkable response. Practically everybody in Sioux City knew Mary Treglia. She had been an outstanding and unusual personality in the community all her life. This Community House to most people was synonymous with Miss Treglia, and her eall for help was an open sesame to all avenues which might have been closed to any ordinary individual.

Miss Treglia's fruitful ingenuity next found additional help for the new Community House project in the very disaster of the depression itself. Because of high taxes during this 1931-3 period, many of the old homes which were regarded as land marks by the pioneers, were being torn down to make way for the down town business district, or for the purpose of saving taxes. Upon the suggestion of Mary Treglia and the committee, the earved woodwork and the beautiful mahogany doors of the old Davidson home were donated to this new Community House. Exquisite iron stair railings and fireplace fixtures from the old Jandt home were donated in addition to marble without end from the Iowa building, which had stood on one of Sioux City's main eorners for generations, but now was being demolished. Lumber, brick, electric light fixtures, radiators, and plumbing from 13 razed buildings were utilized. Even old paving was crushed and mixed again to furnish eonerete for the foundations and floors of the new building, destined to become a land mark of interest and beauty. Through solicitation the committee raised $\$ 4,000$ in eash and donations of building materials amounting to $\$ 10,000$. 
The city architect and electrical inspector with the co-operation of the master electricians donated their services. Most of the laborers furnished by the county relief work project were from the Community House district and, although the county allotted to them a bare minimum of employment hours, their loyalty to the neighborhood and to the project was such that many hours were given without pay. With them it was a labor of love, and the enthusiasm which permeated the arduous toil of grinding and fitting marble, sanding and polishing floors, laying bricks and mixing mortar is a tribute to the importance and desirability of the project. Thus the building valued at $\$ 70,000$ today was constructed with an actual eash outlay of $\$ 4,500$ on the part of the Board.

Although the building was still incomplete, Community House moved into the new building in the early spring of 1934, before all the walls had been plastered. Night School met in the lobby and those who were studying for their eitizenship examinations sat around on the earpenters' benches and discussed the possible questions which might be asked by the examining judge. It was necessary for Miss Treglia and Miss Kinkaid to wear heavy coats while they carried on their work during the next few months until the heating unit was installed.

These months of finishing the interior of the building were full of creative satisfaction. Jack McKelvie deserves much credit for his plan of decoration which was full of color and warmth and beauty. The woodwork in the lobby was painted a lovely vivid blue. The woodwork in the library and the series of class rooms on the west side of the building was painted a copper colored red. Louise Ashley, who had charge of the art classes, painted stars on the floors of the Americanization class rooms and designed the tie-backs for the curtains on which she painted the emblems of the nations. In the library she painted the symbols of the arts. The staff room stressed the color and design of peasant art.

In the spring of 1934, Mrs. Ford, who had served as President of the Board since 1925, died. It was a great blow to the staff, but it gave some comfort to those who mourned her passing that she had lived to see her dream of a new building 
realized. All who had worked with her may be forgiven for asking in their helplessness why she had to lay down her work so soon after secing her vision materialize. A beautiful bronze memorial tablet has been placed on the wall in the foyer as a tribute to her unselfish and loyal unceasing service to Community House.

Mrs. Nilchrist was persuaded to take the presidency again and served two years. Mrs. Arthur Sanford, who had proved her sincere devotion to Community House as a member of the Board and as chairman of the building committee, was the next elected president. Because of her philosophy of life and her willingness to help in every way in which she felt she could serve, Mrs. Sanford is recognized as an invaluable personality in the progress of Community House.

Activities were going in full swing by May. The gymnasium floor was laid and it was hoped that the gym would serve as a reereational center for most of the club work and would help also to relieve the eongestion which Community House has always felt in its work. When everything looked bright and promising and the Men's Club had just finished sanding the new floor, the June flood of 1934 eame in all its fury. The water surrounded the House like a lake and touched the four foot level on the walls. The newly sanded floor bulged so that the boards could be seen sticking up through the water. When the waters receded, the gym presented the most unpleasant and saddest picture one could imagine. For days the stench was almost unbearable. Men from the eity earried out all the flooring that had been laid such a short time ago.

The flood episode was a dramatic epoch in the history of Community House. Early in the morning of June 7, 1934, Miss Treglia began to receive frantic ealls for advice and counsel. At 4:30 in the morning the House was opened as a place of refuge. All the day and night of the 7th Community House was completely marooned. Miss Treglia and Miss Kinkaid and those 40 families who had brought what belongings they could salvage into Community House stood helplessly by and watched the water rise and ruthlessly destroy things that represented years of sacrifice and materials that 
were a source of pride to those who owned them. Meals were prepared for refugees over the one electric plate which the Community House possessed, since there was no gas.

During their emergency set-up, the Red Cross established their office in the Community House building. The Health Department set up headquarters in Community House as the waters went down and gave 2,000 inoculations for typhoid fever. Community House itself distributed clothing during the flood to 265 persons. Community House also assisted the Red Cross with its ease work and distribution of chloride of lime.

After the eatastrophe of 1934, Miss Treglia was determined that Community House should take up the fight to secure help in controlling the flood situation in the Floyd Valley and to remedy an evil which almost annually brought heavy losses of property and untold suffering to hundreds of people in the neighborhood. Yet the flood of 1936 found the community still unprotected from the floods.

In March, 1936, the women in the homes in the district again began to carry the canned goods from the basements and attempted to pile the furniture and bedding as high as possible in anticipation of the flood which was to follow the heavy winter snows. Community House had arranged to temporarily house the refugees up town that year away from the water and possible disease and in a building where meals could be served more satisfactorily.

The bitter feeling about the flood situation reached new heights following the disaster of 1936 . The residents insisted upon some active program being instituted. Fortunately for their cause, the floods in the eastern part of the country arroused sympathy and produced action in the local situation. The WPA and the eity officials worked out plans for the digging of a new channel to lead the Floyd River safely through the valley to the Missouri River. Officials of the WPA and the city appeared at monthly meetings of the residents of the neighborhood at Conimunity House to report on the progress of the flood control plan, to answer questions, and to be impressed that the people in the district were no longer willing to meekly submit to a condition which, with 
the aid of seience, could be averted. It was recognized that without the impetus of Miss Treglia and Community Huase, the work on the river would not have progressed to such a promising degree as it has at the present time.

The later years of Community House have been as full of developments and evidenees of community loyalty as were the earlier years. The Men's Club has had an interesting part in these last few years. The members are those men who helped build the building. They have taken as their project the welfare of the district. As an example of their efforts, they have presented repeated petitions to the police department to rid the neighborhood of its stigma as a red light district.

Since the inception of the government employment program, the Community House has acted as a foeal point for the NYA program in Sioux City. This program is for unemployed and needy youths who receive training in various vocations. They are assigned to various projects such as: homemaking, nursery schools, puppets, library, recreation, carpentry, construction, office work, and many others. The emphasis has been on orientation, training and rehabilitation. Cepha Pasek and Raymond Fisher, both of whom are connected with the Community House activities, act as project supervisors and they deserve unstinted praise for the development of the program.

One of the dreams which Miss Treglia had had for many years was that some day a nursery school might be part of the Community House program. In 1935, Miss Isabel Robinson, then State Supervisor of Emergency Nursery Schools in Iowa, approved the unit being established in Community House. A progressive pre-school program of activities has been instituted for the 50 children in attendance in the morning and afternoon classes; and a valuable program of education in regard to formation of habits and nutrition needs has been subtly carried on with the mothers.

A Well Baby Clinic is one of the newest activities at the Community House. This work was originally started in the old Community House in 1921, but due to inadequate space it was transferred to the Visiting Nurses headquarters in the City Hall. The Junior League is sponsoring this medical 
work in the examination and care of infants of the district.

In the spring of 1934 the American Association of University Women, during the presideney of Mrs. Harry Chandler, became interested in making the library a more effective part of the Community House program. Mrs. J. W. Kindig as chairman of the project undertook the collection of books from members and friends of the AAUW. A committee of workers from the AAUW membership, under the direction of one of the staff from the Public Library, sorted and eatalogued the books. The library has been regularly increased by further donations and the purchase of new books from the fund which the AAUW allotted for that purpose. Magazine subscriptions were given by interested individuals and old copies of Fortune, Time, Reader's Digest, etc., were donated for the racks. At present the library is served by girls from the NYA and WPA. The committee from the AAUW has charge of taking care of the new accumulation of books and the sorting over of the 3,500 volumes which are now on the shelves.

The Experimental Theatre has had an exceptional and consistent growth throughout all the history of Community House. At the present time, the theatre group has as a permanent part of their equipment a portable stage, a black cyclorama and front curtain, and a wardrobe department as well as foot, flood, border, and spot lights. At least four public productions are presented each year and are planned to appeal to varied tastes and to interest both the neighborhood audience and those who help support the project through financial aid. The group holds a meeting once each month, planning a program which is usually of an experimental nature. New plays are reviewed, exhibitions of stage make-up, presentation of one-act plays and talks on subjects relative to the theatre are included in the program. Since there is no other theatrical group in the city at the present time, of any great importance, this theatre serves a need in the community and draws talent from all parts of the eity.

During all these years, Miss Treglia's sphere of influence has been widening, and Community House has been oceupying a more and more important place in this part of the 
country. Miss Treglia was ealled upon to help establish a settlement house for the colored population on the west side of Sioux City and is now acting as supervisor of the Booker T. Washington Community Center. She has served as president of the local Social Workers Club. The NYA sought her advice in establishing the government program. She is in charge of this work with unemployed youths in this district of northwest Iowa. Her ability has been recognized nationally by her appointment on committees of the National Association for the Study of Group Work, the National Conference of Social Work, and the National Institute of Immigrant Welfare Section.

Everyone who has worked with Miss Treglia has felt the impact of her personality, eaught her spirit of devotion and sacrifice to a cause, and has recognized her as a unique figure who lives life to the full. In 1934 she was awarded the Service Medal as the citizen who had contributed most to the welfare of the city during the previous year. Her friendly happy disposition together with a determination to leave the part of the world where she has lived a better place has won her the respect and love of all who know her and has been responsible to a large degree for the success of Community House in Sioux City.

Much eredit also is due the Community House Board, for its faith in and its work for Community House. On the Board now serve Mrs. William Milchrist, Honorary President; Mrs. Arthur Sanford, President; Mrs. J. A. Berry, First Vice President; Mrs. J. W. Kindig, Second Vice President; Mrs. Oscar Ruff, Treasurer; Mrs. Harry Chandler, Secretary; Mrs. J. A. White, Corresponding Secretary; Mesdames T. A. Berry, R. H. Burton-Smith, H. H. Epperson, F. F. Faville, Fritz Fritzson, J. Q. Keeffe, J. L. Kennedy, F. A. MeCornack, W. K. MeGregor, J. A. Newton, C. M. Stillwill, H. Sve, J. W. Wooldrige, C. S. Van Eaton; Miss Georgia W. Lyon. An advisory Board composed of Messers Eugene Kelly, Ralph Oliver, Arthur Sanford, Milton Perry Smith, and G. F. Silknitter also serves.

In summarizing the work of Community House, the pro- 
gram divides into three parts: the service-which includes all the individual case work, the recreational, and the edueational. The extensive program of Community House has necessitated the employment of Miss Frances Petersen as a member of the Community House staff. She has served as a volunteer in the night school and sewing department for some time and her efficient work in the office has helped ease the load of details.

The service work may be illustrated by an exerpt from the annual report for 1936-37 of the Executive Director. "A total of 463 major cases were handled by the Community House service department this past year. Among the problems handled were the following: distribution of surplus commodities, securing a plan for the return to America of an American woman stranded in Italy, securing passports, scholarships, personal letter writting, truancy, adjusting difficulties due to eviction, making out budgets for families, general advice, hospitalizations, securing tonsilectomy, dental aid, securing old age pensions, adjusting family difficulties, giving advice on taxes and insurance, arranging wedding plans, aid in getting $\mathrm{CCC}$ assignments, personality adjustments, aiding Red Cross after flood, aid in securing WPA and NYA assignments, distribution of clothing, Big Brother and Sister care given as well as scores of others."

In the edueational department, the Board of Education has provided a teacher for the English and Americanization classes which have grown in number and effectiveness as time has gone on. The Board of Education of the Public Schools has also furnished a teacher for the art classes and one for the nutrition class which includes housewives who are taught how to prepare a well balanced meal and how to purchase on cheap markets. The food for this class is furnished by the local Red Cross chapter.

There are 75 groups in the recreational department which meet during the course of the week. These include boys and girls athletic elubs, elasses in knitting, art, ereative dramatics, handeraft, and other hobbies, Girl and Boy Seout Troops, the playroom activities, the Girl Homemakers. The Alpha Sigma Club, the oldest in point of history, still leads as one of the 
most effective and influential groups. These business girls meet for a dinner meeting every Monday and contribute programs of worth both from a cultural and social viewpoint. The staff takes pride in the Women of All Nations Club which has shown such unique progress and which represents one of the most firmly established and important activities in the entire program.

Some idea of the tremendous increase of the Community House program is the figure 42,774 which represents the total number of registered attendance in clubs and classes for the year 1936-7.

In such a survey as this it is regrettable that mention eannot be made of all the hundreds of men and women who have made Community House and its program possible. It is a long procession of individuals who have caught the spirit of Community House and devoted themselves in a variety of ways to its welfare and progress. Perhaps the most satisfactory experience to those who have helped in Community House since its inception is to see the youngsters who once participated in Community. House activities grow up and become leaders and advisors of the clubs, the theatre, and the playrooms of the Community House which is theirs.

The history of an institution like Community House eannot be expressed in words. It is written in the lives of those who have given and received the inspiration which has been part of its contribution to the community. Comradeship, goodwill, kindliness, mutual respect and unselfish service constitute the foundation upon which Community House is built. Good citizenship has been the objective of its many activities, a citizenship based on the fundamental value of the individual as a potential benefit to the community.

The eastern mail (via Burlington) due on Friday evening last was detained at the Iowa river. ... The driver attempted to eross, but the ice gave way, and the two wheel horses were drowned-it was with great effort the other two horses and mail were saved. Bloomington Herald, February 26, 1841. 
Copyright of Annals of Iowa is the property of State of Iowa, by \& through the State Historical Society of Iowa and its content may not be copied or emailed to multiple sites or posted to a listserv without the copyright holder's express written permission. However, users may print, download, or email articles for individual use. 